\title{
Faktor - Faktor Yang Mempengaruhi Tingkat Kebahagiaan Masyarakat Yogyakarta Tahun 2017
}

\author{
(Factors Affecting the Happiness Level of the Yogyakarta Society in 2017) \\ Khairunissa Balqis Zhahira ${ }^{1 *}$, Efri Diah Utami ${ }^{2}$ \\ ${ }^{1,2}$ Politeknik Statistika STIS \\ Jalan Otto Iskandardinata No. 64C, Kota Jakarta Timur, DKI Jakarta, 13330 \\ E-mail: 16.9219@stis.ac.id
}

\begin{abstract}
ABSTRAK
Provinsi Yogyakarta mendapat peringkat 8 provinsi paling bahagia di Indonesia yaitu sebesar 72,93. Walaupun Yogyakarta memiliki peringkat Indeks Kebahagiaan cukup tinggi, namun Provinsi Yogyakarta memiliki beberapa permasalahan dari segi ekonomi. Pertama, persentase penduduk miskin di Yogyakarta pada bulan Maret 2017 sebesar 13,02 persen dan pada bulan September 2017 sebesar 12,36 persen, persentase ini di atas rata-rata persentase penduduk miskin tingkat Nasional. Kedua, gini ratio Yogyakarta sebesar 0,432, ini menyebabkan gini ratio Yogyakarta tertinggi di seluruh provinsi di Indonesia, dan permasalahan ketiga, pada tahun 2017 Upah Minimum Provinsi (UMP) Yogyakarta adalah UMP terkecil di seluruh Indonesia, yaitu sebesar Rp. 1.337.645. Oleh karena itu, penelitian ini bertujuan untuk mengetahui gambaran umum dan variabel-variabel yang mempengaruhi tingkat kebahagiaan penduduk Yogyakarta tahun 2017. Metode yang digunakan Regresi Logistik Ordinal. Hasil penelitian menunjukkan tingkat kebahagiaan masyarakat Yogyakarta di pengaruhi oleh variabel usia, pendapatan, kepemilikan tabungan, dan tidak mengalami gangguan kesehatan.
\end{abstract}

Kata kunci: Tingkat Kebahagiaan, Regresi Ordinal, Yogyakarta

\begin{abstract}
Yogyakarta Province is ranked as the 8th happiest province in Indonesia, which is 72.93. Although Yogyakarta has a fairly high Happiness Index rating, Yogyakarta Province has several problems from an economic perspective. First, the percentage of poor people in Yogyakarta in March 2017 was 13.02 percent and in September 2017 it was 12.36 percent, this percentage is above the national average percentage of poor people. Second, the Gini ratio of Yogyakarta is 0.432 , this causes the Gini ratio of Yogyakarta to be the highest in all provinces of Indonesia, and the third problem, in 2017 the Provincial Minimum Wage (UMP) Yogyakarta is the smallest UMP in all of Indonesia, which is Rp. 1,337,645. Therefore, this study aims to find out the general description and variables that affect the happiness of the residents of Yogyakarta in 2017. The method used is Ordinal Logistics Regression. The results showed that the level of happiness of the people of Yogyakarta was influenced by the variables of age, income, savings, and did not experience health problems.
\end{abstract}

Keywords: happiness level, ordinal logistic regression, Yogyakarta

\section{PENDAHULUAN}

Kebahagiaan merupakan kualitas dari keseluruhan hidup manusia. Diener (2013) mengelompokkan komponen aspek kebahagiaan menjadi dua hal, yaitu cognitive component dan affective component. Cognitive commponent memiliki aspek diri sendiri, keluarga, teman sebaya, kesehatan, keuangan, pekerjaan, dan waktu luang. Dengan kata lain Diener, menjelaskan cognitive component berasal dari penerimaan diri sendiri, kasih sayang, prestasi yang diperoleh, hubungan dengan keluarga dan teman, tubuh yang sehat, keuangan yang stabil, dan banyaknya waktu luang. BPS mengeluarkan sebuah indeks komposit yaitu Indeks Kebahagiaan yang bertujuan untuk memenuhi kebutuhan data kesejahteraan subjektif di Indonesia.

Indeks Kebahagiaan merupakan indeks komposit yang disusun oleh tiga dimensi, yaitu Kepuasan Hidup (Life Satisfaction), Perasaan (Affect), dan Makna Hidup (Eudaimonia). Nilai indeks masing-masing dimensi Indeks Kebahagiaan adalah sebagai berikut: (1) Indeks Dimensi Kepuasan Hidup sebesar 71,07; (2) Indeks Dimensi Perasaan (Affect) sebesar 68,59; dan (3) Indeks Dimensi Makna Hidup (Eudaimonia) sebesar 72,23. Seluruh indeks dimensi diukur pada skala 0-100 (BPS, 2017). 


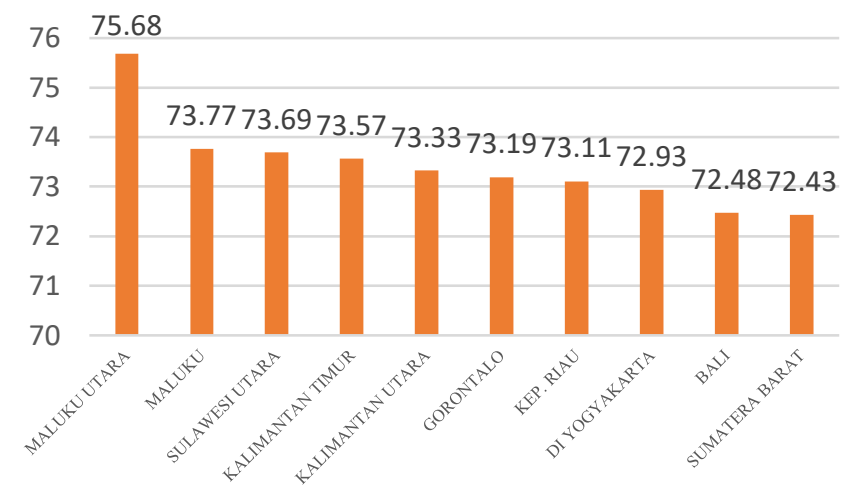

Sumber : BPS, 2017 (diolah)

Gambar 1. 10 Besar Indeks Kebahagiaan Indonesia Tertinggi Menurut Provinsi tahun 2017

Provinsi yang memiliki Indeks Kebahagiaan tertinggi ditempati oleh Provinsi Maluku Utara, dengan Indeks Kebahagiaan sebesar 75,68.Sedangkan, Provinsi Yogyakarta memiliki indeks kebahagiaan sebesar 72,93, ini membuat Provinsi Yogyakarta mendapat peringkat 8 provinsi paling bahagia di Indonesia (BPS, 2017).

Walaupun Yogyakarta memiliki peringkat Indeks Kebahagiaan cukup tinggi, namun Provinsi Yogyakarta memiliki beberapa permasalahan dari segi ekonomi. Permasalahan pertama, pada bulan Maret 2017 persentase penduduk miskin tingkat nasional sebesar 10,64 persen dan pada bulan September 2017 sebesar 10,12 persen, sedangkan persentase penduduk miskin di Yogyakarta pada bulan Maret 2017 sebesar 13,02 persen dan pada bulan September 2017 sebesar 12,36 persen, persentase penduduk miskin di Yogyakarta di atas rata-rata persentase penduduk miskin tingkat nasional (BPS, 2017). Ini sangat berbanding terbalik dengan penelitian yang dilakukan oleh Rahayu (2017) yang menyatakan, pendapatan berhubungan positif dengan kebahagiaan. Permasalahan kedua, pada tahun 2017 gini ratio tingkat nasional sebesar 0,393, namun, gini ratio Yogyakarta sebesar 0,432, ini menyebabkan gini ratio Yogyakarta tertinggi di seluruh provinsi Indonesia, padahal semakin tinggi gini ratio maka semakin besar ketimpangan pendapatan di provinsi tersebut (BPS, 2017). Berbanding terbalik dengan penelitian yang dilakukan oleh Prasetyo (2015) dalam penelitiannya menyatakan: "Semakin tinggi pendapatan perkapita dapat diartikan semakin tinggi tingkat kesejahteraan masyarakat.. Pendapatan berperan penting dalam kesejahteraan di negara berkembang. Permasalahan ketiga, pada tahun 2017 Upah Minimum Provinsi (UMP) Yogyakarta adalah UMP terkecil di seluruh Indonesia, yaitu sebesar Rp. 1.337.645. Ini berbanding terbalik dengan penelitian Ngoo (2015) yang menyatakan bahwa semakin tinggi tingkat pendapatan yang diperoleh individu, semakin tinggi pula peluangnya untuk merasa puas dengan kehidupannya. Ball dan Chernova (2008) juga mengemukakan bahwa absolute dan relative income berpengaruh positif terhadap kebahagiaan.

Berkaitan dengan kondisi di atas, dapat diketahui kebahagiaan masyarakat Yogyakarta berbanding terbalik dengan faktor ekonomi, maka penelitian ini dilakukan dengan tujuan mengetahui gambaran umum dan variabel-variabel yang mempengaruhi tingkat kebahagiaan penduduk Yogyakarta agar nantinya hasil penelitian ini dapat menjadi masukan bagi provinsi lain yang masih memiliki tingkat kebahagiaan rendah.

\section{METODE}

\section{Teori Kebahagiaan}

Teori Maslow (1943) menyatakan bahwa kebutuhan dasar manusia terdiri atas lima tingkatan hierarki yang berbentuk seperti piramida, lima tingkatan terdiri dari : kebutuhan fisiologis (phisiological needs), kebutuhan rasa aman (safety needs), kebutuhan rasa memiliki dan kasih sayang (social needs), kebutuhan penghargaan (esteem needs), kebutuhan aktualisasi diri (self actualization needs). Seligmen (2005) juga menjelaskan individu yang mendapatkan kebahagiaan sejati yaitu individu yang dapat mengidentifikasi dan mengolah yang dimilikinya dan menggunakannya pada kehidupan sehari-hari, baik dalam pekerjaan, cinta, permainan dan pengasuhan. Setiap individu juga memiliki faktor-faktor yang mendatangkan kebahagiaan untuknya. Faktor-faktor itu antara lain, uang, status pernikahan, kehidupan sosial, usia, kesehatan, emosi negatif, pendidikan, iklim, ras, jenis kelamin serta agama atau tingkat religius seseorang. 


\section{Tingkat Kebahagiaan}

Menurut Hurlock (2009) kepuasan hidup merupakan bentuk penilaian individu secara menyeluruh dalam menilai puas atau tidaknya kehidupan yang dialami. Kepuasan hidup akan timbul ketika kebutuhan dan harapan tertentu telah terpenuhi. Pavot dan Diener (1993) mengidentifikasikan kepuasan hidup sebagai proses penilaian yang dilakukan oleh individu terhadap kualitas kehidupan individu tersebut sendiri berdasarkan pada kritea unik. BPS mengukur tingkat kebahagiaan seseorang dari tiga dimensi dan 19 indikator. Pengukuran tiap indikator diukur dengan ladder of life scale dari rentang 0-10. Pada dimensi kepuasan hidup semakin mendekati angka 0, maka semakin tidak puas kehidupan seseorang. Sebaliknya, semakin mendekati angka 10, semakin sangat puas kehidupan seseorang. Pada dimensi perasaan, jika pengukuran perasaan senang/riang/gembira mendekati angka 10 maka semakin senang/riang/gembira kehidupan seseorang. Namun, pada pengukuran perasaan tidak khawatir dan perasaan tidak tertekan, semakin mendekati angka 10, maka semakin menunjukkan perasaan khawatir maupun tertekan. Pada dimensi makna hidup, semakin mendekati angka 0 maka, kehidupan orang tersebut tidak optimis dalam melakukan hal tertentu dalam hidupnya. Sebaliknya, jika mendekati angka 10 maka, seseorang memiliki makna hidup dalam kehidupannya.

\section{Regresi Logistik Ordinal}

Regresi logistik ordinal digunakan ketika outcome dari variabel dependen yang memiliki minimal 3 kategori dan setiap kategori tersebut memiliki tingkatan. Dalam hal outcome dengan skala ordinal, pengkategorian atau pengurutan tingkatan dapat dilakukan dengan jelas, tetapi jarak absolut antar tingkatan kategori tidak diketahui (Agresti, 2010).

\section{Pengujian Asumsi Parallel Lines}

Pengujian asumsi parallel lines adalah untuk memastikan apakah model propotional odds dapat diterapkan. Asumsi ini pun dapat diuji dengan menggunakan uji rasio log likelihood (Azen dan Walker, 2011). Hipotesis dari pengujian asumsi ini yaitu sebagai berikut :

$\mathrm{H}_{0}$ : model menghasilkan nilai koefisien regresi slope yang sama

$\mathrm{H}_{1}$ : model tidak menghasilkan nilai koefisien regresi slope regresi yang sama

Statistik uji :

$\mathrm{PL}=-2 \ln \frac{L_{0}}{L_{1}}$

dimana:

$\mathrm{L}_{0}=$ fungsi likelihood dengan variabel penjelas yang mengasumsikan parallel lines

$\mathrm{L}_{1}=$ fungsi likelihood dengan variabel penjelas yang tidak mengasumsikan parallel lines

Hipotesis nol akan ditolak apabila nilai statistik uji PL $>X^{2}{ }_{p}$ atau nilai p-value $<\alpha$. Jika pengujian menghasilkan gagal tolak Ho, maka dapat diartikan asumsi parallel lines terpenuhi dan model propotional odds dapat digunakan.

\section{Pengujian Kesesuaian Model}

Pengujian goodness of fit bertujuan untuk mengetahui kesesuaian suatu model. Berikut merupakan hipotesis pada pengujian goodness of fit dengan metode Pearson (Agresti, 2010):

$\mathrm{H}_{0}$ : Model sesuai dengan data

$\mathrm{H}_{1}$ : Model tidak sesuai dengan data

Statistik uji :

$\chi^{2}=\sum_{i=1}^{n} \frac{\left(O_{i j}-e_{i j}\right)^{2}}{e_{i j}}$

dimana:

$\mathrm{O}_{\mathrm{ij}}=$ frekuensi observasi ke- $\mathrm{i}$ kategori variabel dependen ke- $\mathrm{j}$

$\mathrm{e}_{\mathrm{ij}}=$ frekuensi harapan ke- $\mathrm{i}$ kategori variabel dependen ke- $\mathrm{j}$

$\mathrm{I}=$ kovariate pattern

$\mathrm{p}=$ banyaknya parameter

Daerah penolakan $\mathrm{H}_{0}$ adalah jika $\chi^{2}>\chi_{(\alpha ;(\mathrm{i}-1) \mathrm{x}(\mathrm{j}-1)-\mathrm{p})}^{2}$ atau $p$-value $<\alpha$ maka dapat disimpulkan 
model sesuai dengan data atau dapat di artikan model dapat di gunakan

\section{Pengujian Signifikasi Parameter secara Simultan}

Pengujian secara simultan, bertujuan untuk memeriksa apakah peran variabel independen yang diberikan terhadap variabel dependen secara bersama-sama dapat dilakukan dengan menggunakan uji Rasio Likelihood. Berikut merupakan hipotesis dari pengujian secara simultan

$\mathrm{H}_{0}: \beta 1=\beta 2=\ldots . .=\beta \mathrm{k}=0$ (seluruh variabel independen $\mathrm{n}$ tidak berpengaruh terhadap variabel dependen) $\mathrm{H}_{1}$ : minimal terdapat satu $\beta \mathrm{k} \neq 0$ (terdapat minimal satu variabel independen yang berpengaruh terhadap variabel dependen), $\mathrm{p}=1,2, \ldots, \mathrm{k}$

Statistik uji :

$G^{2}=-2 \ln \left[\frac{L_{O}}{L_{1}}\right]$

dimana:

$\mathrm{L}_{0}=$ nilai likelihood dari fungsi tanpa variabel independen (Reduced Model)

$\mathrm{L}_{1}=$ nilai likelihood dari fungsi dengan seluruh variabel independen (Full Model).

$\mathrm{p}=$ banyaknya variabel bebas

Jika $\mathrm{G}>\chi_{(\alpha ; p)}^{2}$ atau nilai $p$-value $<\alpha$, maka tolak hipotesis nol. Dapat di artikan bahwa minimal terdapat satu variabel independen yang berpengaruh terhadap variabel dependen.

\section{Pengujian Signifikasi Parameter secara Parsial}

Pengujian secara parsial bertujuan untuk menguji signifikansi dari masing-masing parameter sehingga dapat diketahui variabel independen mana yang memiliki pengaruh nyata terhadap variabel dependen. Berikut merupakan hipotesis dari pengujian secara parsial :

$\mathrm{H} 0: \beta \mathrm{k}=0$ (variabel independen ke-k tidak berpengaruh nyata terhadap variabel dependen)

$\mathrm{H} 1: \beta \mathrm{k} \neq 0$ (variabel independen ke-k berpengaruh nyata terhadap variabel independen), $\mathrm{k}=1,2, \ldots, \mathrm{p}$

Statistik uji :

$W_{k}^{2}=\left[\frac{\widehat{\beta}_{k}}{\operatorname{se}\left(\widehat{\beta}_{k}\right)}\right]^{2}$

dimana:

$\hat{\beta}_{\mathrm{k}}=$ nilai estimasi parameter ke- $\mathrm{k}$

$\operatorname{se}\left(\hat{\beta}_{\mathrm{k}}\right)=$ nilai standar error dari estimasi parameter ke- $\mathrm{k}$

Jika $W_{k}^{2}>\chi_{(\alpha ; 1)}^{2}$ atau nilai $p$-value $<\alpha$, maka tolak $\mathrm{H}_{0}$. Dapat di artikan bahwa variabel independen ke-k berpengaruh terhadap variabel dependen.

\section{Perhitungan Nilai Odds Ratio}

Nilai odds ratio $(\theta)$ menggambarkan kecenderungan suatu bagian populasi pada kategori tertentu terhadap bagian populasi pada kategori lainnya dalam suatu variabel independen yang memiliki pengaruh signifikansi terhadap variabel dependen. Dalam regresi logistik ordinal, odds ratio menggambarkan perbandingan antara odds dari pada atau di bawah sebuah kategori dengan odds berada diatas kategori tersebut. Odds ratio pada kategori $\mathrm{Y}>\mathrm{j}$ adalah perbandingan antara $\mathrm{xk}=1 \mathrm{dan} \mathrm{xk}=0$. Perhitungan odds rasio dapat dirumuskan sebagai berikut :

$\Theta=\frac{P(Y>j \mid k) / P(Y \leq j \mid 1)}{P(Y>j \mid 0) / P(Y \leq j \mid 0)}$
$=\frac{\left[\frac{\exp \left(\alpha_{j}+\beta_{k}\right)}{1+\exp \left(\alpha_{j}+\beta_{k}\right)}\right] /\left[\frac{1}{1+\exp \left(\alpha_{j}+\beta_{k}\right)}\right]}{\left[\frac{\exp \left(\alpha_{j}\right)}{1+\exp \left(\alpha_{j}\right)}\right] /\left[\frac{1}{1+\exp \left(\alpha_{j}\right)}\right]}$ 
$=\exp \left(\hat{\beta}_{k}\right)$

dimana :

$\hat{\beta}_{\mathrm{k}}=$ koefisien estimasi parameter

\section{Metode Pengumpulan Data}

Data yang digunakan dalam penelitian ini berasal dari data sekunder yang bersumber dari Badan Pusat Statistik (BPS) yaitu data Survei Pengukuran Tingkat Kebahagiaan 2017 (SPTK 2017). Survei ini merupakan hasil pengamatan, penilaian objektif, dan hasil penilaian responden yang bersifat subjektif. Pemilihan sampel dengan metode sampel probabilitas dengan memilih 7500 BS (Blok Sensus) secara systematic sampling dari 30000 BS (Blok Sensus) Susenas Maret 2017 dengan memperhatikan distribusi sampel per strata di tingkat kabupaten/kota. Selanjutnya, memilih 20 rumah tangga hasil updating secara systematic sampling dengan implicit stratification pendidikan KRT, 10 rumah tangga untuk Susenas September 2017 dan 10 rumah tangga untuk SPTK 2017. Secara keseluruhan alokasi sampel yang digunakan dalam survei ini adalah 487 Kabupaten/Kota, dengan 7500 sampel blok sensus (4289 rural dan 3211 urban) dan total sampel adalah 75.000 rumah tangga se-Indonesia. Metode pengumpulan data yang di tetapkan SPTK 2017 adalah wawancara langsung terhadap responden dengan menggunakan kuesioner SPTK2017.

\section{HASIL DAN PEMBAHASAN}

\section{Karakteristik Tingkat Kebahagiaan Masyarakat Yogyakarta dan Gambaran Tingkat Kebahagiaan Masyarakat Yogyakarta Berdasarkan Variabel Yang di Duga Mempengaruhi}

Berdasarkan gambar 2, diketahui persentase tingkat kebahagiaan masyarakat Yogyakarta kategori rendah sebesar 34\%, persentase tingkat kebahagiaan kategori sedang sebesar $40 \%$ dan persentase tingkat kebahagiaan kategori tinggi sebesar $26 \%$.

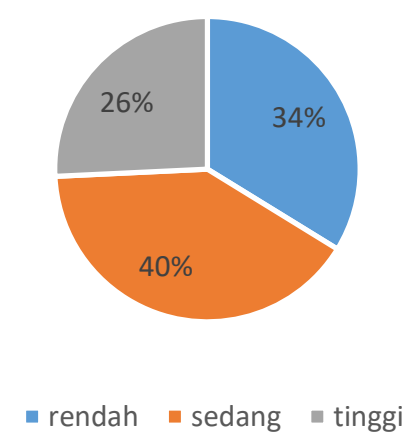

Sumber : SPTK 2017, diolah

Gambar 2. Persentase Masyarakat Yogyakarta berdasarkan tingkat kebahagiaan tahun 2017

Berdasarkan tabel 2, diketahui pada kategori umur, persentase tingkat kebahagiaan tinggi tertinggi dimiliki kategori umur 15-29 tahun dan persentase tingkat kebahagiaan tinggi terendah dimiliki kategori umur $\geq 60$ tahun. Hal ini dapat di sebabkan ketika seseorang memiliki umur yang semakin tua, seseorang akan semakin memiliki tubuh yang lemah dan pertemanan yang semakin kecil, hal ini menyebabkan kepercayaan diri seseorang akan menurun. Ketika kepercayaan diri seseorang menurun, hal ini akan mempengaruhi tingkat kebahagiaan yang juga akan menurun. Pada kategori jenis kelamin, persentase tingkat kebahagiaan tinggi lakilaki lebih tinggi dibandingkan kategori perempuan. Hal ini dipengaruhi oleh perasaan emosional perempuan yang jauh lebih sensitif dibandingkan dengan laki-laki. Menurut penelitian yang dilakukan oleh Suminarsis (2009) perempuan lebih mudah merasakan cemas, perasaan bersalah, gangguan tidur, serta gangguan makan. Pada kategori status perkawinan persentase tingkat kebahagiaan tinggi kategori tidak memiliki pasangan lebih tinggi dibandingkan kategori memiliki pasangan. Pada variabel pendidikan tertinggi yang di tamatkan, persentase tingkat kebahagiaan tinggi $\geq$ SMA lebih tinggi dibandingkan < SMA. Hal ini di sebabkan karena ketika seseorang memiliki pendidikan yang tinggi, akan lebih mudah untuk mendapatkan pekerjaan dan memiliki self esteem lebih tinggi dibandingkan dengan seseorang yang memiliki pendidikan yang rendah. Pada kategori pendapatan, persentase tingkat kebahagiaan tinggi tertinggi dimiliki kategori pendapatan tinggi, lalu 
pendapatan sangat tinggi dan persentase tingkat kebahagiaan tinggi terendah dimiliki kategori pendapatan sangat rendah. Pada variabel kepemilikan tabungan, persentase tingkat kebahagiaan tinggi kategori memiliki tabungan lebih tinggi dibandingkan kategori tidak memiliki tabungan. Hal ini di sebabkan ketika seseorang memiliki tabungan akan memiliki ketenangan hati dan meminimalisir kan seseorang merasakan stress atau perasaan tertekan ketika sewaktu-waktu membutuhkan pengeluaran tidak terduga. Pada variabel kepemilikan gangguan kesehatan, persentase tingkat kebahagiaan tinggi kategori tidak memiliki gangguan kesehatan lebih tinggi dibandingkan kategori memiliki gangguan kesehatan.

Tabel 1. Persentase Tingkat Kebahagiaan Masyarakat Yogyakarta Menurut Variabel Independen

\begin{tabular}{|c|c|c|c|}
\hline \multirow[t]{2}{*}{ Variabel } & \multicolumn{3}{|c|}{ Tingkat Kebahagiaan $(\%)$} \\
\hline & Rendah & Sedang & Tinggi \\
\hline \multicolumn{4}{|l|}{ Umur } \\
\hline 15-29 tahun & 0,22 & 0,43 & 0,35 \\
\hline 30-39 tahun & 0,27 & 0,43 & 0,3 \\
\hline 40-49 tahun & 0,29 & 0,45 & 0,25 \\
\hline 50-59 tahun & 0,39 & 0,38 & 0,23 \\
\hline$>60$ tahun & 0,42 & 0,36 & 0,22 \\
\hline \multicolumn{4}{|l|}{ Jenis Kelamin } \\
\hline Perempuan & 0,33 & 0,42 & 0,25 \\
\hline Laki-Laki & 0,35 & 0,39 & 0,26 \\
\hline \multicolumn{4}{|l|}{ Status Perkawinan } \\
\hline Tidak memiliki pasangan & 0,34 & 0,4 & 0,26 \\
\hline Memiliki Pasangan & 0,33 & 0,43 & 0,24 \\
\hline \multicolumn{4}{|l|}{ Pendidikan Terakhir Yang di Tamatkan } \\
\hline$<$ SMA & 0,44 & 0,35 & 0,21 \\
\hline$\geq$ SMA & 0,25 & 0,45 & 0,3 \\
\hline \multicolumn{4}{|l|}{ Pendapatan } \\
\hline Sangat Tinggi & 0,23 & 0,4 & 0,37 \\
\hline Tinggi & 0,14 & 0,47 & 0,39 \\
\hline Sedang & 0,3 & 0,44 & 0,26 \\
\hline Rendah & 0,31 & 0,43 & 0,26 \\
\hline Sangat Rendah & 0,49 & 0,34 & 0,17 \\
\hline \multicolumn{4}{|l|}{ Kepemilikan Tabungan } \\
\hline Tidak Memiliki Tabungan & 0,46 & 0,34 & 0,2 \\
\hline Memiliki Tabungan & 0,25 & 0,45 & 0,3 \\
\hline \multicolumn{4}{|l|}{ Kepemilikan Gangguan Kesehatan } \\
\hline Tidak memiliki Gangguan Kesehatan & 0,24 & 0,44 & 0,32 \\
\hline Memiliki Gangguan Kesehatan & 0,37 & 0,39 & 0,24 \\
\hline
\end{tabular}

\section{Pengaruh Variabel Independen Terhadap Tingkat Kebahagiaan Masyarakat Yogyakarta}

\section{Uji Asumsi Parallel Lines}

Tabel 2. Hasil uji parallel lines

\begin{tabular}{ccc}
\hline Chi-Square & df & P-value \\
\hline 15,819 & 13 & 0,259 \\
\hline
\end{tabular}

Berdasarkan hasil di atas nilai p-value $>0,05$, dengan tingkat signifikansi 5 persen maka dapat di simpulkan gagal tolak $\mathrm{H}_{0}$ yang berarti koefisien slope untuk kategori tingkat kebahagiaan masyarakat Yogyakarta adalah sama. Sehingga dapat diketahui bahwa asumsi parallel lines terpenuhi dan model propotional odds cocok digunakan. 


\section{Uji Simultan}

Tabel 3. Hasil uji simultan

\begin{tabular}{ccc}
\hline Chi-Square & $\mathrm{df}$ & $P$-value \\
\hline 45,050 & 13 & 0,000 \\
\hline
\end{tabular}

Berdasarkan hasil di atas nilai p-value < 0,05 maka dapat disimpulkan terdapat minimal satu variabel independen berpengaruh terhadap tingkat kebahagiaan masyarakat Yogyakarta.

\section{Uji Kesesuaian Model}

Tabel 4. Hasil uji Pearson

\begin{tabular}{ccc}
\hline Chi-Square & $\mathrm{df}$ & $P$-value \\
\hline 642,208 & 639 & 0,457 \\
\hline
\end{tabular}

Berdasarkan hasil tabel diatas, diketahui bahwa p-value $>0,05$, keputusan yang di per oleh ialah gagal tolak $\mathrm{H}_{0}$, sehingga kesimpulan yang dapat ditarik dengan tingkat signifikansi 5 persen dikatakan model propotional odds dapat digunakan.

\section{Uji Parsial}

Tabel 5. Hasil uji parsial

\begin{tabular}{|c|c|c|c|c|}
\hline Variabel & Notasi & Koefisien & $P$-value & Wald \\
\hline Konstanta 1 & $Y_{1}$ & $-0,583$ & 0,020 & 5,426 \\
\hline Konstanta 2 & $\mathrm{Y}_{2}$ & 1,307 & 0.000 & 26,577 \\
\hline Umur (15-29 tahun) & $\mathrm{D}_{11}$ & 0,567 & $0,024^{*}$ & 5,062 \\
\hline Umur (30-39 tahun) & $\mathrm{D}_{12}$ & 0,273 & 0,203 & 1,623 \\
\hline Umur (40-49 tahun) & $\mathrm{D}_{13}$ & 0,190 & 0,319 & 0,993 \\
\hline Umur (50-59 tahun) & $\mathrm{D}_{14}$ & $-0,142$ & 0,440 & 0,597 \\
\hline Jenis Kelamin (laki - laki) & $\mathrm{D}_{2}$ & 0,037 & 0,781 & 0,077 \\
\hline $\begin{array}{l}\text { Status Perkawinan (tidak } \\
\text { memiliki pasangan) }\end{array}$ & $\mathrm{D}_{3}$ & $-0,134$ & 0,428 & 0,629 \\
\hline $\begin{array}{l}\text { Pendidikan terakhir yang } \\
\text { ditamatkan ( } \geq \text { SMA) }\end{array}$ & $\mathrm{D}_{4}$ & 0,169 & 0,270 & 1,216 \\
\hline $\begin{array}{l}\text { Pendapatan (Pendapatan } \\
\text { sangat tinggi) }\end{array}$ & $\mathrm{D}_{51}$ & 0,942 & $0,000^{*}$ & 14,099 \\
\hline Pendapatan tinggi & $\mathrm{D}_{52}$ & 1,241 & $0,000^{*}$ & 29,442 \\
\hline Pendapatan sedang & $\mathrm{D}_{53}$ & 0,600 & $0,003^{*}$ & 8,827 \\
\hline Pendapatan rendah & $\mathrm{D}_{54}$ & 0,569 & $0,001^{*}$ & 10,795 \\
\hline $\begin{array}{l}\text { Kepemilikan Tabungan } \\
\text { (Tidak memiliki tabungan) }\end{array}$ & $\mathrm{D}_{6}$ & $-0,332$ & $0,027^{*}$ & 4,915 \\
\hline $\begin{array}{l}\text { Mengalami gangguan } \\
\text { kesehatan (Mengalami } \\
\text { gangguan kesehatan) }\end{array}$ & $\mathrm{D}_{7}$ & $-0,471$ & $0,002^{*}$ & 9,711 \\
\hline
\end{tabular}


Berdasarkan dari hasil uji parsial di atas, maka dapat dibentuk persamaan model peluang regresi logistik ordinal sebagai berikut :

$\operatorname{Logit}[P(Y>0 \mid x)]=-0,583+0,567 D_{11}{ }^{*}+0,273 D_{12}+0,190 D_{13}-0,142 D_{14}+0,037 D_{2}-0,134 D_{3}+0,169 D_{4}$ $+0,942 \mathrm{D}_{51}{ }^{*}+1,241 \mathrm{D}_{52}{ }^{*}+0,6 \mathrm{D}_{53}{ }^{*}+0,569 \mathrm{D}_{54}{ }^{*}-0,332 \mathrm{D}_{6}{ }^{*}-0,471 \mathrm{D}_{7}{ }^{*}$

$\operatorname{Logit}[\mathrm{P}(\mathrm{Y}>1 \mid \mathrm{x})]=1,307+0,567 \mathrm{D}_{11}{ }^{*}+0,273 \mathrm{D}_{12}+0,190 \mathrm{D}_{13}-0,142 \mathrm{D}_{14}+0,037 \mathrm{D}_{2}-0,134 \mathrm{D}_{3}+0,169 \mathrm{D}_{4}$ $+0,942 \mathrm{D}_{51}{ }^{*}+1,241 \mathrm{D}_{52}{ }^{*}+0,6 \mathrm{D}_{53}{ }^{*}+0,569 \mathrm{D}_{54}{ }^{*}-0,332 \mathrm{D}_{6}{ }^{*}-0,471 \mathrm{D}_{7}{ }^{*}$

*) Signifikan pada tingkat signifikansi 5 persen

\section{Rasio Kecenderungan (Odds Ratio)}

\section{Umur}

Pada variabel umur, kelompok umur 15-29 tahun memiliki koefisien regresi yang positif. Hal ini menunjukkan bahwa individu yang berumur 15-29 memiliki kecenderungan lebih besar untuk merasa bahagia dibandingkan dengan individu yang berumur lebih dari 60 tahun. Odds ratio yang di per oleh yaitu 1,762. Maka dapat di artikan individu yang berumur 15-29 tahun cenderung memiliki kebahagiaan tinggi sebesar 1,762 kali dibandingkan individu yang berusia lebih dari sama dengan 60 tahun. Dapat diketahui pada usia $\geq$ 60 tahun, tubuh seseorang sudah mulai melemah, lingkungan pertemanan juga semakin kecil dibandingkan dengan seseorang yang memiliki rentang umur 15-29 tahun.

\section{Kepemilikan Tabungan}

Pada variabel kepemilikan tabungan, kategori individu yang tidak memiliki tabungan memiliki koefisien regresi bernilai -0,332. Hal ini menunjukkan individu yang tidak memiliki tabungan cenderung lebih kecil untuk memiliki tingkat kebahagiaan tinggi dibandingkan individu yang memiliki tabungan. Odds ratio yang diperoleh yaitu sebesar 0,717. Maka dapat diartikan individu yang tidak memiliki tabungan cenderung lebih kecil untuk memiliki tingkat kebahagiaan tinggi sebesar 0,717 kali dibandingkan dengan individu yang memiliki tabungan atau dengan kata lain individu yang memiliki tabungan cenderung lebih besar untuk memiliki tingkat kebahagiaan tinggi 1,395 dibandingkan individu yang tidak memiliki tabungan. Dapat diketahui seseorang yang memiliki tabungan lebih memiliki ketenangan hidup, seseorang yang memiliki ketenangan hidup/tidak mengalami kecemasan cenderung lebih bahagia.

\section{Pendapatan}

Pada variabel pendapatan, kategori pendapatan sangat tinggi, tinggi, sedang, rendah memiliki koefisien positif yaitu bernilai $0,942,1,241,0,6,0,569$. Artinya kecenderungan individu yang memiliki pendapatan sangat tinggi, tinggi, sedang, rendah memiliki kecenderungan lebih besar untuk merasa bahagia dibandingkan individu yang memiliki pendapatan sangat rendah. Odds ratio dari kategori pendapatan sangat tinggi, tinggi, sedang, rendah, masing-masing adalah 2,565, 2,238, 1,822, dan 1,767. Artinya, kecenderungan individu yang memiliki pendapatan kategori pendapatan sangat tinggi cenderung lebih besar untuk memiliki tingkat kebahagiaan tinggi 2,565 kali dibandingkan individu yang memiliki pendapatan sangat rendah. Begitu pun juga dengan kecenderungan individu yang memiliki pendapatan tinggi, kategori pendapatan tinggi cenderung lebih besar untuk memiliki tingkat kebahagiaan tinggi 2,238 kali dibandingkan individu yang memiliki pendapatan sangat rendah. Kecenderungan individu yang memiliki pendapatan kategori pendapatan sedang, cenderung lebih besar untuk memiliki tingkat kebahagiaan tinggi 1,822 kali dibandingkan individu yang memiliki pendapatan sangat rendah dan kecenderungan individu yang memiliki pendapatan kategori pendapatan rendah cenderung lebih besar untuk memiliki kebahagiaan tinggi 1,767 kali dibandingkan individu yang memiliki pendapatan sangat rendah. Dapat di simpulkan semakin tinggi pendapatan seseorang, semakin memiliki kecenderungan yang lebih besar untuk memiliki tingkat kebahagiaan tinggi. Hal ini sejalan dengan penelitian yang dilakukan oleh Ngoo (2014) yang menyatakan orang kaya cenderung lebih bahagia dibandingkan dengan orang miskin.

\section{Kesehatan}

Pada variabel kesehatan, individu yang memiliki penyakit/gangguan kesehatan memiliki koefisien regresi negatif yaitu sebesar $-0,471$ dan odds rasio -0,624. Hal ini menunjukkan, individu yang mengalami gangguan kesehatan memiliki kecenderungan lebih kecil untuk memiliki tingkat kebahagiaan tinggi 0,624 kali dibandingkan individu yang sehat/individu yang tidak mengalami gangguan kesehatan atau dengan kata lain, individu yang tidak mengalami gangguan kesehatan cenderung lebih tinggi untuk memiliki kebahagiaan tinggi 1,602 kali dibandingkan individu yang tidak mengalami gangguan kesehatan.. Hal ini sejalan dengan 
penelitian yang dilakukan oleh Easterlin (2003) yang menyatakan kesehatan yang memburuk akan berdampak negatif terhadap tingkat kebahagiaan seseorang dalam waktu yang lain

\section{KESIMPULAN}

Berdasarkan uraian hasil dan pembahasan di atas, kesimpulan yang dapat diambil dari penelitian ini adalah sebagai berikut :

1. Individu yang memiliki umur dengan rentang 15-29 tahun, jenis kelamin laki-laki, tidak memiliki pasangan, pendidikan minimal SMA ke atas, tingkat pendapatan tinggi, memiliki tabungan, dan tidak mengalami gangguan kesehatan, memiliki persentase tingkat kebahagiaan tinggi terbesar di bandingkan dengan kategori lain

2. Variabel yang mempengaruhi tingkat kebahagiaan masyarakat Yogyakarta tahun 2017, variabel umur 15-29 tahu, variabel pendapatan, variabel kepemilikan tabungan, dan variabel mengalami gangguan kesehatan. Sedangkan, variabel yang tidak mempengaruhi tingkat kebahagiaan masyarakat Yogyakarta, yaitu variabel jenis kelamin, status perkawinan/kepemilikan pasangan, dan pendidikan terakhir yang di tamatkan.

\section{DAFTAR PUSTAKA}

Adiati. 2021. Kepuasan Hidup: Tinjauan Dari Kondisi Keuangan Dan Gaya Penggunaan Uang. Surabaya. Universitas Airlangga

Agresti. 2010. Analysis of Ordinal Categorical Data( $\left.2^{\text {nded }}\right)$. New York: John Wiley \& Sons.

Azen and Walker. 2010. Categorical Data Analysis for the Behavioral and Social Sciences. New York : Routledge

Ball, chernova. 2008 Absolute Income, Relative Income, and Happiness. Social Indicators Research: An International and Interdisciplinary Journal for Quality-of-Life Measurement, 2008, vol. 88, issue 3, 497529.

BPS . (2017). Indeks kebahagiaan 2017. Jakarta : Badan Pusat Statistik

Brown, P.\&S. Levinson (1978), Politeness Some Universals in Language Usage, Cambridge: Cambridge University Press

Diener, E., Lucas, R. E., \& Oishi, S. (2002). Sujective well-being: The science of happiness and life satisfaction.

Diener, E. E. 1999. Subjective well-being: Three decades of progress. Psychological Bulletin, Vol.125: 276302.

Easterlin, Richard A. (2003) : Building a Better Theory of Well-Being, IZADiscussion paper series, No. 742

Frey, Bruno dan Alois Stutzer. 2000. Happiness, Economy and Institutions. Economic Journal 110 No. 446: 918-938

Maslow, A. H. (1943). A theory of human motivation. Physological Review

Ngoo. (2014). Determinant of life satisfication in asia. Social indikator Research

Rahayu. (2017). Determinan Kebahagiaan di Indonesia. Jakarta : Unika Atma Jaya

Smyth, J. M., \& Stone, A. A. (2003). Ecological Momentary Assessment research in behavioral medicine. Journal of Happiness Studies: An Interdisciplinary Forum on Subjective Well-Being, 4(1), 35-52.

Sohn, Kitae. 2010. "Considering happiness for economic development: determinants of happiness in Indonesia 